Kerugian Keuangan Negara pada Badan Usaha Milik Negara (BUMN) dalam Perspektif Doktrin

\title{
Business Judgement Rule
}

\author{
Rizky Novian Hartono ${ }^{1 *}$, Sriwati $^{1}$, Wafia Silvi Dhesinta Rini ${ }^{1}$ \\ ${ }^{1}$ Fakultas Hukum, Universitas Surabaya, Surabaya-Indonesia \\ * corresponding author: kikynhartono@gmail.com
}

\begin{abstract}
State-Owned Enterprises that act as an agent of development and business entity for the country are the concrete forms to reach the welfare state goal. Persero, as the example of state-owned enterprises will surely experience advantages and disadvantages due to the dynamic condition of the business world. With the various regulations that regulate state-owned enterprises itself, created a disharmony form of liability to the directors about the business loss. This research aims to identify do the loss of the state-owned enterprises would classified as state financial losses in the perspective of doctrine business judgment rule. This research using statute approach and conceptual approach shows that there is a dualism view about the position of separated-state wealth in the scope of state finances resulting in different interpretations of the meaning of state financial losses by the law enforcers. This dualism view caused a disharmony form of liability that asked to the Directors of Persero when that occur losses because according to the Section 2 and Section 3 Law Number 20 of 2001 jo Law Number 31 of 1999 concerning Eradication of Corruption, the directors would probably asked the liability for the alleged of corruption because causing state financial losses, on the other side according to the Section 97 verse 5 Law number 40 of 2007 concerning Company there is an exception to the directors so they would not be able to be charges. Furthermore, losses that happened in the state-owned enterprises can not only occur as a result of abuse of power but are result of business risks so the directors can be protected by the doctrine of business judgment rule from criminal charge.
\end{abstract}

Keywords: persero state-owned enterprises, state financial losses, business risks, business judgment rule

\begin{abstract}
Abstrak-BUMN sebagai pelaku perekonomian nasional yang memiliki peran ganda yakni sebagai agent of development sekaligus sebagai business entity, merupakan salah satu bentuk konkret perpanjangan tangan negara dalam mewujudkan cita-cita bangsa dan negara yakni memajukan kesejahteraan umum. Layaknya sebuah perusahaan, BUMN Persero sebagai salah satu bentuk BUMN pasti akan mengalami keuntungan maupun kerugian akibat dinamisnya dunia bisnis. Menjadi sebuah problematika ketika kerugian yang dialami oleh BUMN Persero tersebut dihadapkan dengan berbagai peraturan perundang-undangan yang berlaku bagi BUMN, baik dalam ranah hukum publik maupun dalam ranah hukum privat. Penelitian ini bertujuan untuk menelaah apakah kerugian yang dialami oleh BUMN dapat diklasifikasikan sebagai kerugian keuangan negara dalam perspektif doktrin business judgment rule. Melalui penelitian yang dilakukan dengan menggunakan metode statute approach dan conceptual approach ditemukan bahwa adanya dualisme pandangan kedudukan kekayaan negara yang dipisahkan dalam lingkup keuangan negara sehingga menimbulkan perbedaan penafsiran makna kerugian keuangan negara oleh aparat penegak hukum. Dualisme pandangan ini berdampak pada ketidakharmonisan bentuk pertanggungjawaban yang dimintakan kepada Direksi BUMN Persero ketika terjadi kerugian pada tubuh BUMN sebab berdasarkan ketentuan Pasal 2 dan/atau Pasal 3 Undang-Undang Nomor 20 Tahun 2001 jo Undang-Undang Nomor 31 Tahun 1999 tentang Pemberantasan Tindak Pidana Korupsi, Direksi BUMN Persero dapat dimintakan pertanggungjawaban secara pidana atas dugaan tindak pidana korupsi karena menyebabkan kerugian keuangan negara namun berdasarkan Pasal 97 ayat (5) Undang-Undang Nomor 40 Tahun 2007 tentang Perseroan Terbatas terdapat pengecualian agar Direksi BUMN tidak dimintakan pertanggungjawaban secara pribadi. Lebih jauh, kerugian pada BUMN tidak hanya dapat terjadi akibat dari adanya penyalahgunaan wewenang melainkan akibat dari adanya risiko bisnis sehingga doktrin business judgment rule dapat diterapkan untuk memberikan perlindungan bagi direksi dari tuntutan pidana..
\end{abstract}

Kata kunci : badan usaha milik negara, kerugian keuangan negara, risiko bisnis, business judgment rule

\section{PENDAHULUAN}

Perekonomian merupakan suatu bidang vital dan strategis dalam penyelenggaraan kehidupan berbangsa dan bernegara bahkan pembangunan ekonomi selalu menjadi agenda penting serta fokus utama dalam setiap perumusan kebijakan pemerintah yang berkuasa. Tujuan berbangsa dan bernegara Indonesia pun sebagaimana yang termaktub dalam alinea ke-4 Pembukaan Undang-Undang Dasar Negara Republik Indonesia Tahun 1945 tak luput mencantumkan kesejahteraan umum sebagai tonggak pembangunan bangsa Indonesia sebab pada dasarnya maju tidaknya perekonomian suatu negara menentukan keberlangsungan kehidupan berbangsa dan bernegara. Sebagai negara hukum, Indonesia tidak pernah lepas untuk mendasarkan penyelenggaraan pemerintahan pada konstitusi sebagai hukum dasar. Melalui Pasal 33 Undang-Undang Dasar Negara Republik Indonesia Tahun 1945, sejatinya telah mengamanatkan kepada pemerintah untuk turut serta dalam urusan perekonomian nasional dan kesejahteraan sosial. Hal tersebut merupakan konsekuensi dianutnya konsep Negara kesejahteraan (welfare state) sebagai konsep negara yang menghendaki agar negara turut mencampuri kepentingan warga negaranya. Sebagaimana yang diungkapkan oleh Esping- Enderson dalam Triwibowo 
\& Bahagijo (2006, hal. 9), “Negara kesejahteraan pada dasarnya mengacu pada peran negara yang aktif dalam mengelola dan mengorganisasi perekonomian yang di dalamnya mencakup tanggung jawab negara untuk menjamin ketersediaan pelayanan kesejahteraan dasar dalam tingkat tertentu bagi warga negaranya." Dengan demikian, Indonesia bukanlah sebuah negara yang hanya mengatur serta memberikan jaminan terhadap keamanan warga negaranya atau sebagai negara penjaga malam (nachtwachterstaat), tetapi lebih daripada itu yakni turut bertanggung jawab pula atas kesejahteraan sosial dan ekonomi.

Bentuk keterlibatan negara Indonesia untuk mewujudkan pemenuhan kebutuhan dasar warga negara diejawantahkan dengan adanya pendirian suatu Badan Usaha Milik Negara, selanjutnya disingkat BUMN, yang dalam perjalanannya turut menghasilkan barang dan/atau jasa bagi masyarakat. Dalam Penjelasan Umum angka 1 Undang-Undang Nomor 19 Tahun 2003 tentang Badan Usaha Milik Negara, selanjutnya disebut Undang-Undang BUMN, mengeksplanasikan bahwa BUMN merupakan salah satu pelaku ekonomi dalam sistem perekonomian nasional, di samping usaha swasta atau koperasi. Pasal 1 angka 1 Undang- Undang BUMN mendefinisikan BUMN sebagai suatu badan usaha yang penyertaan modalnya berasal dari kekayaan negara yang dipisahkan. Didirikannya BUMN pada hakekatnya merupakan bentuk konkret negara menjalankan kewenangan yang dimilikinya yakni menguasai cabang-cabang produksi penting yang berkenaan dengan hajat hidup orang banyak. Dengan kata lain, BUMN merupakan perpanjangan tangan negara dalam melayani kepentingan publik melalui pengelolaan cabang-cabang strategis yang tidak dapat dikelola oleh badan usaha lainnya sekaligus untuk mencapai tujuan bangsa.

Berkenaan dengan status BUMN, Indroharto dalam Ridwan HR yang dikutip oleh Henny Juliani (2016, hal. 302) menyatakan bahwa, "BUMN/BUMD dimasukkan sebagai instansi Pemerintah". Demikian pula dengan kedudukan Direksi BUMN sebagai pengurus berdasarkan penjelasan Pasal 2 angka 7 Undang-Undang Nomor 28 Tahun 1999 tentang Penyelenggaraan Negara yang Bersih dan Bebas dari Korupsi, Kolusi dan Nepotisme adalah sebagai pejabat negara sebab memiliki fungsi strategis dalam kaitannya dengan penyelenggaraan negara sesuai dengan ketentuan peraturan perundang-undangan yang berlaku. Modal dari BUMN itu sendiri merupakan dan berasal dari kekayaan negara yang dipisahkan, yang berdasarkan ketentuan Pasal 2 huruf g Undang-Undang Nomor 17 Tahun 2003 tentang Keuangan Negara, selanjutnya disebut Undang-Undang Keuangan Negara, termasuk dalam salah satu ruang lingkup keuangan negara. Berdasarkan klasifikasi tersebut dapat diketahui bahwa BUMN diatur dengan hukum publik yang pada akhirnya memberikan kewenangan pada Badan Pemeriksa Keuangan, selanjutnya disingkat BPK, melalui Pasal 6 ayat (1) Undang-Undang Nomor 15 Tahun2006 tentang Badan Pemeriksa Keuangan, selanjutnya disebut Undang-Undang Badan Pemeriksa Keuangan, untuk memeriksa pengelolaan dan tanggung jawab keuangan negara yang dilakukan oleh BUMN. Di samping itu dalam menjalankan kegiatan usahanya, BUMN yangberbentuk Persero harus tunduk pada ketentuan yang diatur dalam Undang-Undang Nomor 40 Tahun 2007 tentang Perseroan Terbatas, selanjutnya disebut Undang-Undang Perseroan Terbatas, sebagaimana yang diamanatkan melalui Pasal 11 UndangUndang BUMN.

Dengan berlakunya pula Undang-Undang Perseroan Terbatas menimbulkan konflik norma sebab dengan adanya pengakuan kekayaan negara yang dipisahkan termasuk dalam salah satu ruang lingkup keuangan negara menjadikan setiap kerugian yang terjadi di BUMN diklasifikasikan sebagai kerugian keuangan negara sehingga direksi dimintakan pertanggungjawaban secara pidana atas tindak pidana korupsi sebagaimana yang diatur dalam Pasal 2 ayat (1) Undang-Undang Nomor 20 Tahun 2001 jo Undang-Undang Nomor 31 Tahun 1999 tentang Pemberantasan Tindak Pidana Korupsi, selanjutnya disebut Undang-Undang Tipikor, yang menentukan bahwa :

"Setiap orang yang secara melawan hukum melakukan perbuatan memperkaya diri sendiri atau orang lain atau suatu korporasi yang merugikan keuangan negara atauperekonomian negara, dipidana penjara dengan penjara seumur hidup atau pidana penjara paling singkat 4 (empat) tahun dan paling lama 20 (dua puluh) tahun dan denda paling sedikit Rp. 200.000.000,00 (dua ratus juta rupiah) dan paling banyak Rp. 1.000.000.000,00 (satu milyar rupiah)."

Layaknya suatu perusahaan pada umumnya, BUMN sebagai perpanjangan tangan dari negara yang menguasai cabang-cabang produksi penting yang berkenaan dengan hajat hidup orang banyak serta menguasai sumber daya alam Indonesia dalam operasionalnya tidak selalu berjalan dengan mulus. BUMN selalu dituntut untuk terus berinovasi dan mampu bersaing agar hakekat didirikannya suatu BUMN dapat terealisasi. Dalam operasional suatu BUMN, keputusan yang dibuat oleh direksi sematamata merupakan suatu kewajiban bagi direksiuntuk dapat mengembangkan bisnis BUMN namun suatu realita yang tidak dapat dihindari adalah suatu badan usaha pasti akan mengalami keuntungan maupun 
kerugian. Dengan kerangka berpikir demikian maka kerugian yang dialami oleh BUMN tidak hanya disebabkan karena adanya penyalahgunaan wewenang yang dilakukan oleh direksi namun juga sangat dimungkinkan terjadi akibat dari adanya risiko bisnis.

Sejatinya dalam hukum perusahaan, terdapat doktrin yang telah dikenal secara luas yakni doktrin business judgment rule. Boen (2008, hal. 9) mengungkapkan bahwa "Doktrin business judgment rule merupakan suatu doktrin yang mengajarkan bahwa suatu putusan direksi mengenai aktivitas perseroan tidak boleh diganggu gugat oleh siapapun, meskipun putusan tersebut kemudian ternyata salah atau merugikan perseroan." Pada dasarnya melalui ketentuan Pasal 97 ayat (5) Undang-Undang Perseroan Terbatas memberikan ruang pengecualian bagi direksi untuk dimintakan pertanggungjawaban penuh secara pribadi. Pada akhirnya, dengan berbagai macam peraturan perundang-undangan yang mengatur BUMN menimbulkan ketidakharmonisan bentuk pertanggungjawaban yang dimintakan kepada direksimanakala terjadi kerugian pada BUMN.

\section{METODE}

Jenis metode penelitian yang digunakan adalah yuridis-normatif dengan melakukan studi kepustakaan terhadap bahan-bahan hukum baik bahan hukum primer yaitu peraturan perundangundangan dan bahan hukum sekunder yaitu literatur yang berkaitan dengan topik permasalahan. Metode penelitian yang digunakan terdiri dari berbagai cara dan kegiatan yang dilakukan dalam rangka mengumpulkan data-data dari bahan-bahan hukum yang diperlukan. Pendekatan masalah yang digunakan adalah statute approach yakni melakukan pendekatan melalui telaah terhadap undangundang serta regulasi yang terkait dengan isu hukum yang dibahas serta conceptual approach yaitu pendekatan dengan berpedoman pada pandangan serta doktrin para ahli yang berkembang dalam ilmu hukum sedangkan bahan hukum yang digunakan meliputi bahan hukum primer yaitu peraturan perundang-undangan terkait antara lain Undang-Undang Nomor 17 Tahun 2003 tentang Keuangan Negara, Undang-Undang Nomor 19 Tahun 2003 tentang Badan Usaha Milik Negara, Undang-Undang Nomor 20 Tahun 2001 jo Undang-Undang Nomor 31 Tahun 1999 tentang Pemberantasan Tindak Pidana Korupsi, Undang-Undang Nomor 40 Tahun 2007 tentang Perseroan Terbatas sekaligus Putusan Mahkamah Konstitusi Nomor 62/PUU-XI/2013, serta bahan hukum sekunder, adalah bahan hukum yang bersumber dari pendapat ilmiah para sarjana dan buku-buku literatur yang berkaitan dengan kerugian keuangan negara, doktrin business judgment rule serta Badan Usaha Milik Negara.

\section{HASIL DAN BAHASAN}

Sebagaimana yang diatur dalam Pasal 1 angka 1 Undang-Undang BUMN menentukan bahwa BUMN adalah badan usaha yang seluruh atau sebagian besar modalnya dimiliki oleh negara melalui penyertaan secara langsung yang berasal dari kekayaan negara yang dipisahkan. Sebagai salah satu pelaku perekonomian nasional, BUMN ikut berperan menghasilkan barang dan/atau jasa. Di samping itu, BUMN juga mempunyai peran strategis sebagai pelaksana pelayanan publik, penyeimbang kekuatan-kekuatan swasta besar, dan turut membantu pengembangan usaha kecil/koperasi. BUMN juga merupakan salah satu sumber penerimaan negara yang signifikan dalam bentuk berbagai jenis pajak, dividen dan hasil privatisasi.

Peran BUMN tersebut diwujudkan dalam bentuk pelaksanaan kegiatan usaha pada hampir seluruh sektor perekonomian, seperti sektor pertanian, perikanan, perkebunan, kehutanan, manufaktur, pertambangan, keuangan, pos dan telekomunikasi, transportasi, listrik, industri dan perdagangan, serta konstruksi. Seiring dengan berkembangnya dunia usaha dengan tantangannya yang semakin kompleks, pemerintah mendorong agar BUMN dapat terus eksis dengan melakukan ekspansi bisnis agar mendapatkan keuntungan maupun manfaatyang sebesar-besarnya bagi kemakmuran rakyat. Keberadaan BUMN menurut Faisal (2003, hal.11), "Sudah menjadi gejala umum di dunia, negara-negara dengan sengaja ikut serta dalam usaha perdagangan dengan membentuk perusahaan-perusahaan. Maksud dari keikutsertaan itu tidak lain adalah agar laba atau keuntungan yang diperoleh dapat digunakan untuk membiayai jalannya pemerintahan negara dalam rangka menjalankan tugas publiknya." Demikian pula menurut Penulis sebab maju tidaknya perekonomian suatu negara menentukan keberlangsungan kehidupan berbangsa dan bernegara.

Maksud dan tujuan pendirian BUMN berdasarkan ketentuan Pasal 2 ayat (1) Undang- Undang BUMN ialah:

a. Memberikan sumbangan bagi perkembangan perekonomian nasional pada umumnya dan penerimaan negara pada khususnya;

b. Mengejar keuntungan; 
c. Menyelenggarakan kemanfaatan umum berupa penyediaan barang dan/atau jasa yang bermutu tinggi dan memadai bagi pemenuhan hajat hidup orang banyak;

d. Menjadi perintis kegiatan-kegiatan usaha yang belum dapat dilaksanakan olehsektor swasta dan koperasi;

e. Turut aktif memberikan bimbingan dan bantuan kepada pengusaha golongan ekonomi lemah, koperasi, dan masyarakat.

BUMN dapat melaksanakan kegiatan usahanya didasarkan pada modal layaknya perusahaan pada umumnya. Modal BUMN merupakan dan berasal dari kekayaan negara yang dipisahkan yaitu kekayaan negara yang berasal dari Anggaran Pendapatan dan Belanja Negara (APBN) untuk dijadikan penyertaan modal negara pada Persero dan/atau Perum serta perseroan terbatas lainnya. Penyertaan modal negara dalam rangka pendirian atau penyertaan BUMN tersebut sebagaimana yang dimaksud pada Pasal 4 ayat (2) Undang-Undang BUMN bersumber dari:

a. Anggaran Pendapatan dan Belanja Negara;

b. Kapitalisasi cadangan;

c. sumber lainnya.

Sebagaimana yang tercantum dalam Pasal 9 Undang-Undang BUMN yang menentukan bahwa BUMN terdiri dari Persero dan Perum. Kedua jenis BUMN tersebut memiliki maksud dan tujuan yang berbeda namun pada pokoknya merupakan perusahaan negara yang digunakan oleh negara sebagai alat untuk memenuhi kebutuhan hidup masyarakatnya. Khusus untuk Persero, sebagaimana yang dimaksud dalam Pasal 11 undang-undang $a$ quo berlaku ketentuan dan prinsip yang diatur dalam Undang-Undang Perseroan Terbatas.

Kekayaan negara yang dipisahkan sebagai penyertaan modal negara pada BUMN termasuk dalam salah satu ruang lingkup dari keuangan negara sebagaimana yang dirumuskan dalam Pasal 2 huruf g Undang-Undang Keuangan Negara bahwa, "Kekayaan negara/kekayaan daerah yang dikelola sendiri atau oleh pihak lain berupa uang, surat berharga, piutang, barang,serta hak-hak lain yang dapat dinilai dengan uang termasuk kekayaan yang dipisahkan pada perusahaan negara/perusahaan daerah.

Kedudukan kekayaan negara yang dipisahkan yang termasuk ruang lingkup keuangan negara diperkuat dengan adanya Putusan Mahkamah Konstitusi Nomor 62/PUU-XI/2013. Dalam pertimbangannya menyebutkan bahwa:

"Bahwa, menurut Mahkamah, pemisahan kekayaan negara dimaksud dilihat dari perspektif transaksi bukanlah merupakan transaksi yang mengalihkan suatu hak, sehingga akibat hukumnya tidak terjadi peralihan hak dari negara kepada BUMN, BUMD, atau nama lain yang sejenisnya. Dengan demikian kekayaan negara yang dipisahkan tersebut masih tetap menjadi kekayaan negara."

Kedudukan kekayaan negara yang dipisahkan sebagai salah satu ruang lingkup keuangan negara erat kaitannya dengan sejarah pembentukan undang-undang yang mengatur mengenai keuangan negara. Pengaturan mengenai keuangan negara memiliki landasan konstitusional berdasarkan Pasal 23C Undang-Undang Dasar Negara Republik Indonesia Tahun 1945 yang menentukan bahwa, "Halhal lain mengenai keuangan negara diatur dengan undang-undang". Melalui amanat konstitusi tersebut, diundangkanlah paket undang-undang keuangan negara yang terdiri dari Undang-Undang Keuangan Negara, Undang-Undang Perbendaharaan Negara, dan Undang-Undang Pemeriksaan Pengelolaan dan Tanggung Jawab Keuangan Negara.

Paket undang-undang keuangan negara menjadi sebuah gebrakan baru yang dilakukan oleh Dewan Perwakilan Rakyat mengingat bahwa hingga tahun 2003, peraturan perundangundangan yang digunakan untuk mengelola keuangan negara serta pemeriksaan pertanggungjawaban keuangan negara merupakan produk hukum dari Hindia Belanda yakni Indische Comptabiliteitswet (ICW Stbl. 1925 No. 448), selanjutnya diubah dan diundangkan dalam Lembaran Negara 1954 No. 6, 1955 No. 49, dan terakhir Undang-Undang Nomor 9 Tahun 1968, yang ditetapkan pertama kali pada tahun 1864, Indische Bedrijvenwet (IBW) Stbl. 1927 No. 419 jo Stbl. 1936 No. 445 dan Reglement voor het Administratief Beheer (RAB) Stbl. 1933 No. 381 serta Instructie en verdure bepalingen voor de Algemeene Rekenkamer (IAR) Stbl. 1933 No. 320, yang kesemuanya diberlakukan berdasarkan Aturan Peralihan Undang-Undang Dasar Negara Republik Indonesia Tahun 1945. 
Pembentukan Undang-Undang Keuangan Negara merupakan tuntutan reformasi di bidang keuangan negara untuk menjawab tantangan serta kebutuhan pengaturan keuangan negara yang lebih modern serta komprehensif agar dapat mengatasi berbagai problematika yang dihadapi dalam kehidupan berbangsa dan bernegara yang tidak dapat diakomodir penyelesaiannya melalui peraturan perundang-undangan produk hukum Hindia Belanda sekaligus disesuaikan dengan jiwa bangsa yang terkandung dalam konstitusi sebab pada dasarnya penyelenggaraan pemerintahan negara untuk mewujudkan tujuan bernegara menimbulkan hak dan kewajiban negara yang dapat dinilai dengan uang. Oleh sebab itu, politik hukum paket perundang-undangan di bidang keuangan negara diarahkan pada terciptanya pengelolaan keuangan negara secara profesional dalam rangka kesejahteraan dan kemakmuran masyarakat. Dimana dalam rangka mewujudkan suatu kondisi perekonomian nasional yang dapat mensejahterahkan warga negaranya maka juga tidak lepas dari kondisi dan pengelolaan atas keuangan negara.

Penjabaran dari ruang lingkup keuangan negara dalam hukum positif menurut para ahli merupakan deskripsi dalam arti luas. Penjabaran ruang lingkup keuangan negara yang sangat luas tersebut bukanlah tanpa alasan. Agustinus dalam tesisnya (2011, hal. 7) mengemukakan bahwa "Perumusan definisi dan cakupan keuangan negara yang sangat luas dalam paket undang-undang keuangan negara, sesungguhnya didasarkan pada kesadaran filosofis untuk mengedepankan pencapaian tujuan negara sebagaimana yang dirumuskan dalam konsideran menimbang huruf a Undang-Undang Keuangan Negara."

Tidak hanya itu, luasnya definisi keuangan negara yang diatur dalam Undang-Undang Keuangan Negara dipandang mengandung napas teori neo konservatisme. Teori neo konservatisme memahami keuangan negara dalam 3 (tiga) hal, yakni:

a. Negara sebagai faktor kekuasaan tertinggi dalam lapangan hukum publik maupun hukum privat;

b. Campur tangan organ negara terhadap mekanisme pemeriksaan keuangan publik;

c. Menguatnya pengaruh birokrasi negara dalam pengelolaan dan pengawasan sektor privat.

Pandangan ini dikemukakan oleh Dian sebagaimana dilansir dalam laman Direktorat Jenderal Peraturan Perundang-Undangan Kementerian Hukum dan Hak Asasi Manusia (Ditjenpp.kemenkumham.go.id, tanpa tahun) bahwa:

"Neo konservatisme melacak keuangan negara sebagai seluruh kekayaan negara dimanapun sehingga menumbuhkan kesadaran yang bersifat konkret dan substantif bahwa keuangan negara ada dimana-mana. Hal ini berarti keuangan negara bersumber, berasal, dan berkembang dari negara yang akhirnya berujung pada kepemilikan negara. Definisi dan ruang lingkup keuangan negara yang dirumuskan secara luas/komprehensif tersebut dimaksudkan untuk mencegah adanya loopholes dalam regulasi yang bisa berimplikasi terhadap terjadinya kerugian negara dalam hal pengelolaan keuangan negara."

Selain itu, sebagaimana yang dikutip oleh Ikhwan dalam bukunya (2016, hal. 18) bahwa penafsiran keuangan negara dilakukan pula melalui pendekatan sistematik dan teleologis atau sosiologis terhadap keuangan negara yang dapat memberikan penafirsan yang relatif lebih akurat sesuai dengan tujuannya. Maksudnya adalah:

"Apabila pengertian keuangan negara pendekatannya dilakukan dengan cara penafsiran sistematis teleologis maka pengertian keuangan negara itu adalah dalam pengertian keuangan negara dalam arti luas, yakni termasuk di dalamnya keuangan yang berada dalam APBN, APBD, BUMN/D, dan pada hakikatnya seluruh kekayaan negara yang merupakan obyek pemeriksaan dan pengawasan."

Seperti yang tampak pada gambar bahwa keuangan BUMN diatur oleh berbagai peraturan perundang-undangan yang jumlahnya lebih banyak dibandingkan dengan peraturan perundang-undangan yang mengatur badan hukum swasta sehingga berdampak pada tidak leluasanya BUMN dalam menjalankan perusahaan, terutama agar dapat bersaing dengan 
kompetitor.

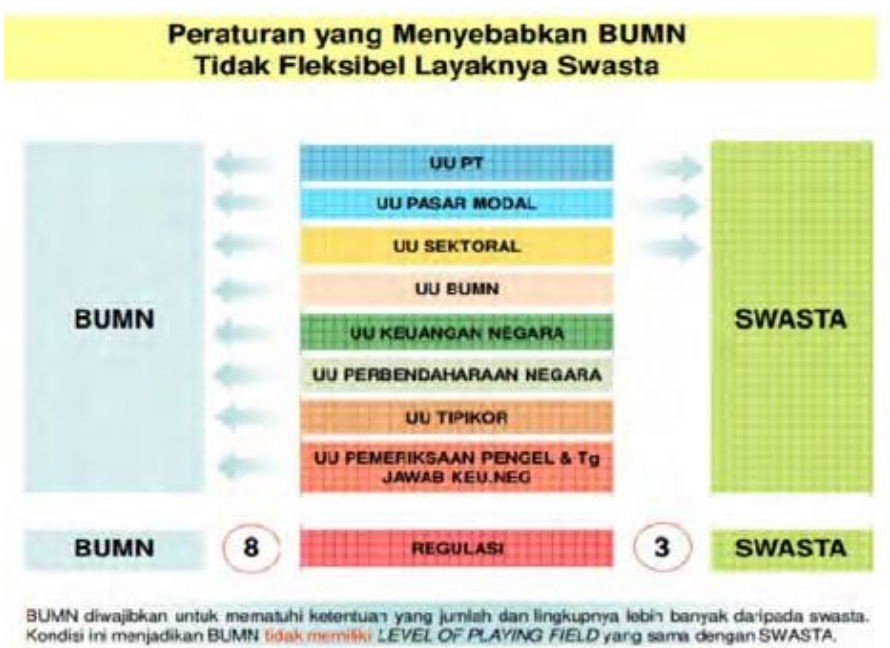

Sumber: Zainul sebagaimana mengutip dari Agus Adhari, Kedudukan Keuangan Badan Usaha Milik Negara terhadap Keuangan Negara.

Definisi keuangan negara yang luas menjadikan kekayaan negara yang dipisahkan termasuk dalam ruang lingkup keuangan negara sebagaimana yang diatur dalam Undang- Undang Keuangan Negara dan Undang-Undang Tipikor. Cakupan tersebut kemudian menimbulkan perdebatan banyak kalangan, tak terkecuali para ahli hukum. Perdebatan- perdebatan tersebut menjadikan adanya dualisme pandangan kedudukan keuangan BUMN terhadap keuangan negara. Riawan Tjandra dalam disertasi Hendry (2018, hal. 50) pun mengungkapkan bahwa,

“Dalam perspektif hukum administrasi negara, paradigma pengelolaan BUMN tak boleh berlari meninggalkan prinsip dasar yang terkandung dalam Pasal 33 UUD Negara RI 1945. Oleh karena itu, seharusnya ruh dalam pengelolaan BUMN tetap diarahkan untuk mewujudkan kesejahteraan rakyat dan negara tak boleh kehilangan kendali pengawasan atas tata kelola BUMN."

Tetapi bagi kalangan yang berpendapat bahwa kekayaan negara yang dipisahkan sebagai sumber dan merupakan modal bagi BUMN termasuk dalam ranah keuangan negara adalah hal yang tidak tepat mendasarkan argumentasi pada asas dan prinsip dari perseroan terbatas itu sendiri. Arifin sebagaimana yang dikutip oleh Rukly dalam jurnalnya (2015, hal. 52) mengemukakan pendapat bahwa:

"Dikaitkannya dengan modal negara pada BUMN berbentuk hukum Perusahaan Perseroan (Persero) ialah akibat putusnya hubungan antara keuangan negara yang ditanamkan dalam bentuk saham pada Perseroan Terbatas (Persero) dengan keuangan negara sehingga keuangan negara dalam bentuk saham tersebut tidak dapat dikatakan lagi status hukumnya sebagai keuangan publik, tetapi telah berubah status hukumnya sebagai keuangan privat yang sepenuhnya tunduk pada Undang-Undang No. 40 Tahun 2007 tentang PerseroanTerbatas"

Dualisme pandangan tersebut menciptakan iklim kontradiktif serta polemik status kekayaan negara yang dipisahkan pada BUMN. Kerancuan tersebut pada akhirnya menimbulkan kesulitan untuk memberikan batasan yang pasti, jelas, serta tegas terhadap terjadinya kerugian pada BUMN masuk dalam ranah publik atau ranah privat. Tetapi satu hal yang pasti bahwa tidak semua kerugian yang terjadi pada BUMN merupakan kerugian keuangan negara yang pada akhirnya dapat menjerat direksi dengan tindak pidana korupsi. Kerugian pada BUMN juga sangat dimungkinkan terjadi akibat dari adanya risiko bisnis BUMN dalam menjalankan perusahaan. Risiko bisnis tersebut merupakan hasil dari keputusan yang telah dijalankan oleh direksi dengan itikad baik, bertanggung jawab, serta dengan penuh kehati-hatian sebelumnya. Kerugian keuangan negara dapat terjadi pada BUMN ketika adanya perbuatan melawan hukum yang dilakukan oleh direksi. Lebih spesifik lagi, direksi dalam menjalankan kewenangannya telah melakukan penyalahgunaan wewenang yang tidak sesuai dengan peraturan perundang-undangan dan anggaran dasar yang telah ditetapkan.

BUMN Persero sebagai badan hukum yang merupakan suatu subjek hukum, dalam melakukan perbuatan hukum dilakukan oleh organ-organ BUMN. Berkaitan dengan itu, Gunawan dalam bukunya 
(2008, hal. 41) mengemukakan bahwa "Dengan demikian berarti pada dasarnya Persero juga dijalankan oleh orang perorangan yang duduk dan menjabat sebagai pengurus perseroan (Direktur) yang berada dalam satu wadah/ organ yang dikenal dengan nama Direksi."

Berdasarkan ketentuan Pasal 5 ayat (1) Undang-Undang BUMN menentukan bahwa, "Pengurusan BUMN dilakukan oleh Direksi." Dalam menjalankan kepengurusan tersebut, direksi bertanggung jawab penuh atas pengurusan BUMN untuk kepentingan dan tujuan BUMN, serta mewakili BUMN, baik di dalam maupun di luar pengadilan." Sebagaimana yang ditentukan dalam Pasal 15 Undang-Undang BUMN menentukan bahwa Direksi diangkat dan diberhentikan oleh RUPS, dimana apabila Menteri bertindak selaku RUPS maka pengangkatan dan pemberhentian Direksi ditetapkan oleh Menteri. Pengangkatan direksi yang telah melalui mekanisme uji kelayakan dan kepatutan kemudian melahirkan hubungan fiduciary relation, yang selanjutnya melahirkan fiduciary duty. Fiduciary duty membawa implikasi bagi Direksi bahwa Direksi harus menjalankan tugasnya dengan penuh tanggung jawab. Asep (2018, hal. 18) mengungkapkan bahwa Fiduciary duty direksi mengandung prinsip-prinsip sebagai berikut:

a. Direksi dalam melakukan tugasnya tidak boleh ditujukan untuk kepentingan pribadi ataupun kepentingan pihak ketiga, tanpa persetujuan dan atau sepengetahuan perseroan;

b. Direksi tidak boleh memanfaatkan kedudukannya sebagai pengurus untuk memperoleh keuntungan, baik untuk dirinya sendiri maupun pihak ketiga, kecuali atas persetujuan perseroan;

c. Direksi tidak boleh menggunakan atau menyalahgunakan aset perseroan untuk kepentingannya sendiri dan/atau pihak ketiga.

Dinamisnya perkembangan dunia usaha menuntut direksi harus dapat mengambil keputusan yang tepat dalam waktu yang cepat pula agar Persero dapat tetap berkembang dengan tidak mengindahkan kecermatan dalam mengambil keputusan tersebut. Apabila direksi dalam mengambil keputusan tersebut telah dilakukan dengan penuh tanggung jawab, itikad baik, telah melakukannya dengan pertimbangan yang matang, maka mengingat pada suasana dunia usaha yang tidak dapat dipastikan, apabila keputusan yang dilakukan oleh direksi dalam menjalankan aksi korporasi berujung pada timbulnya kerugian pada Perseromaka seharusnya direksi tidak dituntut penuh secara pribadi, karena pada dasarnya keputusan tersebut tidak dilakukan atas dasar adanya conflict of interest, telah sesuai dengan wewenang yang dimiliki bahkan tidak mengandung perbuatan melawan hukum. Dengan begitu, direksi akan mendapatkan perlindungan melalui business judgment rule setelah direksi menjalankan fiduciary duty.

Boen (2008, hal. 9) mengungkapkan bahwa "Doktrin business judgment rule merupakan suatu doktrin yang mengajarkan bahwa suatu putusan Direksi mengenai aktivitas perseroan tidak boleh diganggugugat oleh siapapun, meskipun putusan tersebut kemudian ternyata salah atau merugikan perseroan." Asep (2018, hal. 33) mengemukakan bahwa terdapat 2 (dua) konsepsi berpikir business judgment rule yakni:

a. Business judgment rule sebagai standard of review Konsepsi berpikir ini membolehkan pengadilan untuk memeriksa dan meneliti secara objektif terhadap kualitas putusan direksi walaupun dilakukan secara limitatif; dan

b. Business judgment rule sebagai abstention doctrine Konsepsi berpikir ini tidak membolehkan dilakukannya judicial review dan dihadapkan dengan undang-undang terhadap putusan direksi yang telah memenuhikriteria business judgment rule.

Sejatinya, eksistensi business judgment rule telah diatur dalam hukum positif secara implisit melalui ketentuan Pasal 97 ayat (5) Undang-Undang Perseroan Terbatas yang menentukan bahwa:

Anggota Direksi tidak dapat dipertanggungjawabkan atas kerugian sebagaimana dimaksud pada ayat (3) apabila dapat membuktikan:

a. Kerugian tersebut bukan karena kesalahan atau kelalaiannya;

b. Telah melakukan pengurusan dengan itikad baik dan kehati-hatian untuk kepentingan dan sesuai dengan maksud dan tujuan Perseroan;

c. Tidak mempunyai benturan kepentingan baik langsung maupun tidak langsung 
atastindakan pengurusan yang mengakibatkan kerugian; dan

d. Telah mengambil tindakan untuk mencegah timbul atau berlanjutnya kerugiantersebut"

Dari ketentuan normatif Pasal 97 ayat (5) Undang-Undang Perseroan Terbatas tampak bahwa Direksi dapat lepas tanggung jawab dari kerugian negara apabila dapat membuktikan kerugian tersebut bukan dari kesalahan atau lalai, dan telah melakukan kepengurusan dengan hati-hati dan secara itikad baik, tidak memiliki benturan kepentingan, serta telah melakukan pencegahan

Masih dipukul ratanya pemahaman kerugian yang terjadi pada BUMN merupakan kerugian keuangan negara oleh aparat penegak hukum mengakibatkan direksi selalu dibayang-bayangi dengan jerat sanksi pidana sebab telah melakukan tindak pidana korupsi. Persamaan definisi kerugian keuangan negara tidak lepas dari penafsiran keuangan negara yang luassehingga memasukkan kekayaan negara yang dipisahkan masuk ke dalam salah satu ruang lingkup keuangan negara. Meskipun kekayaan negara yang dipisahkan secara normatif dimasukkan sebagai ruang lingkup keuangan negara namun aparat penegak hukum harus mampu menafsirkan kerugian keuangan negara secara komprehensif dan bijaksana agar tidak seluruh kerugian yang terjadi pada BUMN diklasifikasikan sebagai kerugian keuangan negara sebab dapat dimungkinkan kerugian itu terjadi karena risiko bisnis. Persamaan perlakuan ini menyebabkan banyak direksi tumbang dengan dijadikan sebagai terdakwa atas tindak pidana korupsi. Maka dari itu, disini dokrin business judgment rule sebagai doktrin dalam hukum bisnis harus mampu menampakkan taringnya untuk melindungi para direksi BUMN Persero yang telah dengan mencurahkan seluruh tenaganya untuk melakukan pengurusan BUMN Persero dengan itikad baik dan bertanggung jawab sesuai dengan ketentuan peraturan perundang- undangan dan anggaran dasar Persero

Penyamaan perlakuan atas terjadinya kerugian keuangan negara, baik yang terjadi karena adanya unsur perbuatan melawan hukum akibat penyalahgunaan wewenang ataupun terjadi karena risiko bisnis tampaknya disadari oleh Mahkamah Konstitusi. Dalam Putusan Mahkamah Konstitusi Nomor 62/PUU-XI/2013, Mahkamah berpendapat bahwa:

“...kekayaan negara tersebut telah bertransformasi menjadi modal BUMN atau BUMD sebagai modal usaha yang pengelolaannya tunduk pada paradigma usaha (business judgement rules), namun pemisahan kekayaan negara tersebut tidak menjadikan beralih menjadi kekayaan BUMN atau BUMD yang terlepas dari kekayaan negara, karena dari perspektif transaksi yang terjadi jelas hanya pemisahan yang tidak dapat dikonstruksikan sebagai pengalihan kepemilikan, oleh karenanya tetap sebagai keuangan negara dan dengan demikian kewenangan negara di bidang pengawasan tetap berlaku. Meskipun demikian, paradigma pengawasan negara dimaksud harus berubah, yakni tidak lagi berdasarkan paradigma pengelolaan keuangan negara dalam penyelenggaraan pemerintahan (government judgement rules), melainkan berdasarkan paradigma usaha (business judgement rules)."

Dengan telah diperkenalkannya pula business judgment rule oleh Mahkamah Konstitusi agar diterapkan dalam melakukan pengawasan serta pemeriksaan pengelolaan dan tanggung jawab keuangan negara terhadap BUMN membawa arti bahwa ketika BPKmenemukan kerugian pada BUMN maka tidak serta merta kerugian tersebut dinyatakan sebagai kerugian keuangan negara. BPK harus menelusuri lebih jauh apakah kerugian yang terjadi pada BUMN tersebut murni atas risiko bisnis yang dilakukan oleh direksi atau tidak. Apabila hasil pemeriksaan tersebut menunjukkan bahwa direksi telah menjalankan kewenangannya sesuai dengan prinsip-prinsip yang terkandung pada fudiciary duty, serta direksi telah melakukan pengurusan dengan penuh tanggung jawab, itikad baik, tidak ada konflik kepentingan, dilakukan semata-mata untuk kepentingan perseroan sekaligus telah melakukan langkahlangkah kajian terlebih dahulu maka sepatutnya kerugian itu dinyatakan sebagai akibat dari risiko bisnis sehingga kerugian yang dialami oleh BUMN tidak selalu dapat disidik dan dituntut ke meja hijau.

Pemahaman akan prinsip business judgment rule yang telah diuraikan di atas ini pula sejatinya menjadi sebuah pemahaman yang harus diketahui dan diseragamkan pemaknaannya kepada seluruh aparat penegak hukum agar ketika penyidik, penuntut umum hingga hakim memeriksa suatu perkara kerugian yang melibatkan BUMN maka pengadilan sudah selayaknya terlebih dahulu memeriksa dengan menerapkan prinsip-prinsip business judgment rule. Dengan dilakukannya pemeriksaan pada persidangan dengan menerapkan prinsip-prinsip business judgment rule maka sejatinya hakim sedang melakukan pemeriksaan dengan menggunakan konsepsi business judgment rule sebagai standard of 
review.

Pada dasarnya menurut Reny (2017, hal. 177) dalam Prosiding Seminar Nasional menyatakan bahwa:

"Tanggung jawab pidana adalah tanggung jawab pribadi. Dalam kaitan dengan tindak pemerintahan, tanggung jawab pribadi seorang pejabat berhubung dengan adanya maladministrasi. Tanggung gugat perdata dapat menjadi tanggung gugat jabatan berkaitan dengan perbuatan melanggar hukum oleh penguasa. Tanggung gugat perdata menjadi tanggung gugat pribadi apabila terdapat unsur maladministrasi. Tanggung gugat TUN pada dasarnya adalah tanggung gugat jabatan."

\section{SIMPULAN}

Berdasarkan pembahasan yang telah diuraikan di atas maka dapat disimpulkan bahwa terdapat problematika mengenai pertanggungjawaban yang dimintakan kepada direksi BUMN Persero ketika terjadi kerugian pada tubuh BUMN. Hal ini diakibatkan oleh beberapa faktor diantaranya adalah:

Keuangan negara secara normatif didefinisikan secara luas oleh pembentuk undang-undang sebagaimana yang diatur di dalam Undang-Undang Keuangan Negara, Undang-Undang Perbendaharaan Negara, Undang-Undang Pemeriksaan Pengelolaan dan Tanggung Jawab Keuangan Negara sekaligus di dalam Undang- Undang Tipikor. Landasan filosofis yang melatarbelakangi keuangan negara didefinisikan secara luas yakni agar negara dapat mencegah terjadinya penyalahgunaan pengelolaan keuangan negara untuk menjalankan amanat Pasal 33 Undang-Undang Dasar Negara Republik Indonesia Tahun 1945. Dengan demikian definisi keuangan negara yang luas berikut dengan pengelolaan BUMN harus tetap diarahkan pada terwujudnya kesejahteraan rakyat sebab kesejahteraan rakyat merupakan hukum tertinggi (salus populi, suprema lex).

Adanya dualisme pandangan kedudukan kekayaan negara yang dipisahkan pada BUMN sebagai salah satu ruang lingkup keuangan negara sehingga menimbulkan perbedaan penafsiran makna kerugian keuangan negara. Melihat problematika yang terjadi, Mahkamah Konstitusi memberikan masukan bahwa perlu adanya model pengawasan khusus terkait dengan BUMN sebab pada dasarnya tidak setiap kerugian yang dialami oleh BUMN serta merta diklasifikasikan sebagai kerugian keuangan negara. Kerugian pada BUMN juga dapat terjadi akibat risiko bisnis dalam menjalankan perusahaan. Kerugian pada BUMN diklasifikasikan sebagai kerugian keuangan negara manakala kerugian tersebut terjadi akibat adanya perbuatan melawan hukum yakni penyalahgunaan wewenang yang dilakukan oleh direksi BUMN sebagai pejabat Negara.

Doktrin business judgment rule yang secara normatif diatur dalam Pasal 97 ayat (5) UndangUndang Perseroan Terbatas dapat diimplementasikan pada direksi yang dimintakan pertanggungjawaban pidana apabila terjadi kerugian pada BUMN ketika telah dijalankannya fiduciary duty oleh direksi sekaligus terpenuhinya unsur-unsur yang diatur dalam Pasal 97 ayat (5) UndangUndang Perseroan Terbatas. Oleh karena itu, terhadap topik permasalahan yang ada maka disarankan untuk membuat sebuah aturan agar memberikan kepastian, kejelasan, serta ketegasan berkenaan dengan kerugian yang dialami oleh BUMN tidak serta merta diklasifikasikan sebagai kerugian keuangan negara. Di sisi lain, dibutuhkan sebuah model pengawasan khusus terhadap BUMN Persero yang didasarkan pada paradigma usaha (business judgment rule) sehingga dengan begitu direksi dapat menjalankan perusahaan tanpa dibayang-bayangi dengan sanksi pidana mengingat karakteristik khusus yang dimiliki oleh BUMN yang tidak hanya berperan sebagai agent of development namun juga sekaligus sebagai business entity.

\section{PUSTAKA ACUAN}

Arifin, Muhammad Zainul dan Firman Muntaqo. (2018). Penerapan Prinsip Detournement De Pouvoir terhadap Tindakan Pejabat BUMN yang Mengakibatkan Kerugian Negara Menurut UndangUndang Nomor 17 Tahun 2003 tentang Keuangan Negara. Jurnal Nurani, Vol. 18, No. 2, Desember 2018

Boen, Hendra Setiawan. (2008). Bianglala Business Judgment Rule. Jakarta: PT. Tatanusa. Fahrojih, Ikhwan. (2016). Pengfawasan Keuangan Negara Pemeriksaan Keuanga Negara Melalui Auditor Internal dan Eksternal serta DPR. Malang: Intrans Publishing.

Dadi, Agustinus Ferdinandus Paskalino. (2011). Kepastian Hukum tentang Status Keuangan Negara di Lingkungan BUMN Persero dan Implikasinya terhadap Masalah Kerugian Negaradalam Penyelesaian Tindak Pidana Korupsi. Tesis pada Program Studi Magister Ilmu HukumProgram Pascasarjana Universitas Atma Jaya Yogyakarta. 
Juliani, Henny. (2016). Pertanggungjawaban Direksi BUMN Terhadap Perbuatan yang Mengakibatkan Kerugian Keuangan Negara. Masalah - Masalah Hukum, Jilid 45, No. 4, Oktober 2016.

Mokoginta, Rukly. (2015). Analisis Hukum Bisnis tentang Kerugian Keuangan pada Badan Usaha Milik Negara. Lex Crimen, Vol. IV/No.6/Ags/2015Mulyana, Asep N. (2018). Business Judgment Rule Praktik Peradilan Terhadap Penyimpangan Dalam Pengelolaan BUMN/BUMD. Jakarta: PT. Grasindo.

Nendissa, Reny Heronia. (2017). Pertanggungjawaban Kerugian Negara dalam Perspektif Hukum Administrasi Negara. Prosiding Seminar Nasional Pertanggungjawaban Hukum Terhadap Pengelolaan Keuangan Negara Fakultas Hukum Universitas Jenderal Soedirman.

Noor, Hendry Julian. (2018). Kerugian Keuangan Negara dalam Pengelolaan Badan Usaha Milik Negara Berbentuk Perseroan Terbatas Perspektif Hukum Bisnis dan Tindak Pidana Korupsi. Disertasi pada Program Doktor Ilmu Hukum Fakultas Hukum Universitas Gajah Mada.

Undang-Undang Dasar Negara Republik Indonesia Tahun 1945

Undang-Undang Nomor 19 Tahun 2003 tentang Badan Usaha Milik Negara

Undang-Undang Nomor 28 Tahun 1999 tentang Penyelenggaraan Negara yang Bersih danBebas dari Korupsi, Kolusi dan Nepotisme

Undang-Undang Nomor 17 Tahun 2003 tentang Keuangan Negara

Undang-Undang Nomor 15 Tahun 2006 tentang Badan Pemeriksa Keuangan

Undang-Undang Nomor 40 Tahun 2007 tentang Perseroan Terbatas

Undang-Undang Nomor 20 Tahun 2001 jo Undang-Undang Nomor 31 Tahun 1999 tentang Pemberantasan Tindak Pidana Korupsi

Putusan Mahkamah Konstitusi Nomor 62/PUU-XI/2013,

Salam, Moch. Faisal. (2003). Pemberdayaan BUMN di Indonesia. Bandung: Penerbit Pustaka.

Triwibowo, Darmawan; \& Bahagijo, Sugeng. (2006). Mimpi Negara Kesejahteraan. Jakarta: LP3ES

Widjaja, Gunawan. (2008). Risiko Hukum sebagai Direksi, Komisaris \& Pemilik PT. Jakarta:Niaga Swadaya.

Yuliani, Andi. Direktorat Jenderal Peraturan Perundang-Undangan Kementerian Hukum dan Hak Asasi Manusia Republik Indonesia. Keuangan Negara dan Keuangan Publik, diambil dariditjenpp.kemenkumham.go.id. 